\title{
"The impact of social distancing policy on small and medium-sized enterprises (SMEs) in Indonesia"
}

\begin{tabular}{|c|c|}
\hline \multirow{5}{*}{ AUTHORS } & Muhtar Lutfi (D https://orcid.org/0000-0002-1648-9555 \\
\hline & Pricylia Chintya Dewi Buntuang (D http://orcid.org/0000-0001-5351-2307 \\
\hline & Yoberth Kornelius (D) https://orcid.org/0000-0003-0747-0438 \\
\hline & Erdiyansyah (D https://orcid.org/0000-0001-8037-8959 \\
\hline & Bakri Hasanuddin (D https://orcid.org/0000-0002-2830-911X \\
\hline ARTICLE INFO & $\begin{array}{l}\text { Muhtar Lutfi, Pricylia Chintya Dewi Buntuang, Yoberth Kornelius, Erdiyansyah } \\
\text { and Bakri Hasanuddin (2020). The impact of social distancing policy on small } \\
\text { and medium-sized enterprises (SMEs) in Indonesia. Problems and Perspectives } \\
\text { in Management, 18(3), 492-503. doi:10.21511/ppm.18(3).2020.40 }\end{array}$ \\
\hline DOI & http://dx.doi.org/10.21511/ppm.18(3).2020.40 \\
\hline RELEASED ON & Monday, 12 October 2020 \\
\hline RECEIVED ON & Wednesday, 22 July 2020 \\
\hline \multirow[t]{2}{*}{ ACCEPTED ON } & Saturday, 03 October 2020 \\
\hline & $(\mathrm{oc}) \mathrm{EY}$ \\
\hline LICENSE & $\begin{array}{l}\text { This work is licensed under a Creative Commons Attribution } 4.0 \text { International } \\
\text { License }\end{array}$ \\
\hline JOURNAL & "Problems and Perspectives in Management" \\
\hline ISSN PRINT & $1727-7051$ \\
\hline ISSN ONLINE & $1810-5467$ \\
\hline PUBLISHER & LLC "Consulting Publishing Company "Business Perspectives" \\
\hline FOUNDER & LLC "Consulting Publishing Company "Business Perspectives" \\
\hline
\end{tabular}

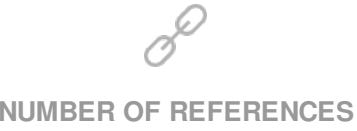

53
NUMBER OF FIGURES

2
NUMBER OF TABLES

1

(C) The author(s) 2022. This publication is an open access article. 


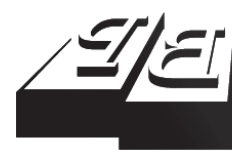

\section{BUSINESS PERSPECTIVES}

(O)

LLC "CPC "Business Perspectives" Hryhorii Skovoroda lane, 10, Sumy, 40022, Ukraine www.businessperspectives.org
Received on: $22^{\text {nd }}$ of July, 2020 Accepted on: $3^{\text {rd }}$ of October, 2020 Published on: $12^{\text {th }}$ of October, 2020

() Muhtar Lutfi, Pricylia Chintya Dewi Buntuang, Yoberth Kornelius, Erdiyansyah, Bakri Hasanuddin, 2020

Muhtar Lutfi, Dr., Associate Professor, Department of Economics and Development Studies, Faculty of Economics and Business, Tadulako University, Indonesia. (Corresponding author)

Pricylia Chintya Dewi Buntuang, M.Sc. Lecturer, Department of Management, Faculty of Economics and Business, Tadulako University, Indonesia.

Yoberth Kornelius, M.Sc., Associate Professor, Department of Management, Faculty of Economics and Business, Tadulako University, Indonesia.

Erdiyansyah, M.Sc, Lecturer, Department of Public Administration, Faculty of Social and Political Science, Tadulako University, Indonesia.

Bakri Hasanuddin, Dr., Associate Professor, Department of Management, Faculty of Economics and Business, Tadulako University, Indonesia.
Muhtar Lutfi (Indonesia), Pricylia Chintya Dewi Buntuang (Indonesia),

Yoberth Kornelius (Indonesia), Erdiyansyah (Indonesia), Bakri Hasanuddin (Indonesia)

\title{
THE IMPACT OF SOCIAL DISTANCING POLICY ON SMALL AND MEDIUM-SIZED ENTERPRISES (SMES) IN INDONESIA
}

\begin{abstract}
This study aims to investigate the impact of social distancing policies on SMEs in Indonesia. It used a quantitative method with a survey design. Respondents were all SMEs in Indonesia that are affected by social distancing policies during the COVID-19 pandemic. It involved a total of 587 SME samples selected randomly. The data were collected through observations, questionnaires, and literature studies. The collected data were analyzed using descriptive statistics with SPSS software to determine the mean value. The result showed that social distancing policies affect SMEs during the COVID-19 pandemic. This is indicated by the decreasing income and demand for SMEs products, and even some have no income (mean values of 2.40) due to the social distancing policies. Besides, the policy's impact is also shown in the increasing cost of raw materials and production costs due to supply chain problems (mean values of 4.79). The policy's impact raises anxiety for SMEs to survive so that business actors change their plans by utilizing information technology (mean values of 4.81). This change is a strategy to survive due to the impact of the applied policies. Although social distancing policies affect SMEs' survival during the pandemic, research findings show that SMEs in Indonesia did not terminate employment (mean values of 4.37) due to the presence of economic stimulus policies that helped SMEs survive and grow during the COVID-19 pandemic.
\end{abstract}

Keywords

JEL Classification

\section{INTRODUCTION}

COVID-19 is a pandemic causing a global health emergency. This pandemic does affect not only health but also the global economy, including in Indonesia. The COVID-19 pandemic is extremely dangerous because of its quick transmission from person to person and causing death. Thus, it forces many countries to implement control policies. Control policies cover contact tracing, isolation, quarantine, social distancing, community detention, work from home, and large-scale social restrictions. This study focuses on the social distancing policy in which its implementation affects the survival of small and medium-sized enterprises (SMEs). The social distancing policy is one of the recommended policies by the World Health Organization (WHO) to stop the transmission of this virus, and it has been applied in some countries. The social distancing policy requires the public to maintain distance and reduce activity in public places to stop the virus's spread.

Indeed, a long time ago, other viruses such as $\mathrm{H} 5 \mathrm{~N} 1$ and influenza virus have spread globally. Previous research has examined the virus control in various countries. During the H5N1 virus, most Southeast Asia countries implemented mass detention policy to reduce the spread 
of the virus (Ferguson et al., 2005, 2006). It indicates that the implementation of social distancing policy is crucial to cut down the spread of deadly virus transmitted from human to human, such as COVID-19. Previous research found that some countries applied similar mass detention policies to stop the spread of the virus. During the current pandemic, many countries have also implemented the detention policy, such as social distancing policy. The H5N1 virus occurred in various countries, but it differs from the COVID-19, which spreads quickly throughout the world. The influenza virus did not spread throughout the world and did not significantly affect the global economy. However, the COVID-19 virus greatly affects the global economy. This condition requires many countries to implement social distancing policy affecting SMEs.

The implementation of social distancing policy causes economic gaps. A previous study found that the social distancing policy was causing social-economic burdens (Baum, Jacobson, \& Goold, 2009). In Indonesia, the impact of the COVID-19 pandemic on the economy is more severe than the previous economic in 1997-1998, which stop the economic activity as a great number of companies closed down the business resulting in extremely high unemployment. This study distinguishes the influenza virus and the 1997-1998 economic crisis in Indonesia. The previous study has not shown a massive impact as COVID-19 pandemic, so the current study is crucial as the pandemic has wider impacts. Not all countries are affected by the influenza virus, and only some countries that applied social distancing policy. Therefore, the economic activity, including exports, still runs, but in this current pandemic, almost all countries have implemented this policy, and it has stopped the economic activity, including export.

Meanwhile, the previous economic crisis only affected big business in which SMEs could still actively run its export activities and support the Indonesian economy. However, the current pandemic affected wider sectors, including SMEs. In 1998, SMEs became the savior of the Indonesian economy. When many large businesses and banks collapsed, SMEs' exports increased by 350\% (Santia, 2020). On the other hand, the current pandemic has greatly affected SMEs requiring the government to establish an economic stimulus policy to save SMEs.

The explanation above shows that this study is crucial because it is new and different from the previous studies. It aims to identify the impact of social distancing policy on SMEs in Indonesia. This study is expected to contribute to economic growth, especially for SMEs, there is another pandemic requiring social distancing policy in the future.

\section{LITERATURE REVIEW}

The global COVID-19 (coronavirus disease) greatly affects the economic conditions as the government does not respond it well (Gustavsson \& Larsson, 2020; Wang, Hong, Li, \& Gao, 2020; Zachariadis, Ozcan, \& Dinçkol, 2020). This global pandemic has caused an economic crisis and stopped trading activities (Javed \& Ayaz, 2020; Yi, 2020) due to the lockdown policy. The implemented lockdown policy aims to stop the transmission of the virus; meanwhile, it highly affects economic activity and employment (Brussevich, Dabla-Norris, \& Khalid, 2020a; Brussevich, Dabla-Norris, \& Khalid, 2020b).

The COVID-19 pandemic affects all sectors of the economy (Omar, Ishak, \& Jusoh, 2020). One of the most vulnerable sectors affected by this pandemic is small and medium-sized enterprises (SMEs) (Javed \& Ayaz, 2020; Winarsih, Indriastuti, \& Fuad, 2020). Globally and nationally, the COVID-19 pandemic threatens SMEs' survival (Gustavsson \& Larsson, 2020). This situation is influenced by government policies, such as social distancing (Barrot et al., 2020), isolation, household quarantine, closure of schools or workplaces, travel restrictions (Ferguson et al., 2006), and stay home.

The new severe acute respiratory syndrome Coronavirus 2 (SARS-CoV-2) was found in December 2019 in Wuhan City, Hubei Province, China. It spread throughout China and then on February 12, 2020, the World Health Organization officially called it coronavirus disease 2019 
(COVID-19) (Huang et al., 2020; Zu et al., 2020) as it has become a pandemic and a global health issue (Clerkin et al., 2020). COVID-19 spreads from person to person through respiratory droplets and direct contact (Huang et al., 2020; World Health Organization, 2020). In many countries, the control of the transmission of COVID-19 used the same measures such as contact tracing, isolation, quarantine, social distancing, community detention (Wilder-Smith \& Freedman, 2020), work from home (Brynjolfsson et al., 2020), and LargeScale Social Restriction (PSBB) policy in Jakarta, Indonesia (Syafri, Sangadji, \& Utami, 2020).

Reducing activities that gather many people or reducing social contact is the only strategy to prevent the transmission of COVID-19 that does not involve pharmacy (Lewnard \& Lo, 2020). Reducing public activities and social contact is a social distancing step. Social distancing is an effective control measure in managing the pandemic (R. Glass, L. Glass, Beyeler, \& Min, 2006). Social distancing includes the closure of schools, work from home, and quarantine (Imai et al., 2020). School closure is the first way to respond to a pandemic (Cauchemez et al., 2009). The key to social distancing is to do self-isolation and seek remote medical advice unless the symptoms are severe (Anderson, Heesterbeek, Klinkenberg, \& Hollingsworth, 2020). Self-isolation means withdrawing from the crowd and learning things that can benefit yourself to avoid the virus's spread and transmission.

Besides affecting health, COVID-19 also has a major impact on the economy, employment, and public welfare (Bartik et al., 2020b; Nyanga \& Zirima, 2020; OECD, 2020a). The impact on the global economy is significant (Papadopoulos, Baltas, \& Balta, 2020). Many countries have implemented measures to control COVID-19 through isolation, quarantine, social distancing, community detention, work from home (WFH), and large-scale social restrictions, which are specifically applied in Indonesia. Those policies have affected SMEs in various countries, including Indonesia, due to their limited assets, low capital reserves, and low productivity compared to large companies. Therefore, it threatens the sustainability of SMEs.

The social distancing policy was implemented because due to health care crisis caused by
COVID-19 (Farboodi, Jarosch, \& Shimer, 2020). Prevention of COVID-19 transmission causes economic and health problems (Jones, Philippon, \& Venkateswaran, 2020). It requires the government to take action as the policy might affect the economic condition. This policy's implementation is very important because the vaccine has not been found yet (Weill, Stigler, Deschenes, \& Springborn, 2020). All implemented policies to prevent COVID-19 transmission throughout 2020 aim to reduce death rates, but they impact the economy.

Concerning the economy, the implementation of social distancing has made SMEs' sales declined due to the prohibition of activities in public places. However, it is believed that SMEs can be successful during a pandemic if they comply with health protocols (Saidu \& Aifuwa, 2020). Social distancing is practiced by changing behavior and reducing direct contact activities to reduce virus transmission (Reluga, 2010). Social distancing is an important element in preventing humans from the transmission of viruses. Further, social distancing is applied to carry out mitigation during a pandemic (Ahmed, Zviedrite, \& Uzicanin, 2018). Mitigation measures through social distancing are one of the measures outside medical or non-pharmaceutical that can prevent transmission of the virus.

COVID-19 has affected all aspects, but there is a greater concern about implementing social lockdowns or social distancing that affects SMEs (Thorgren \& Williams, 2020). Moreover, SMEs greatly influence and become an important measure for the world economy. During the crisis, SMEs become very vulnerable, especially in terms of financial perspective (Doshi, Kumar, \& Yerramilli, 2017; Herbane, 2010). In Indonesia, the government has tried to reduce the socio-economic impact of COVID-19 by restructuring SMEs' loan policy, assistance for poor and vulnerable households, and tax and credit incentives for business (OECD, 2020b).

The implementation of this policy is expected to provide a positive impact on SMEs in Indonesia. The poor condition of SMEs in Indonesia affected by the COVID-19 pandemic has led the researcher to conduct this study. This poor condition is caused by a government-controlled policy resulting in gaps in the field, in which many SMEs op- 


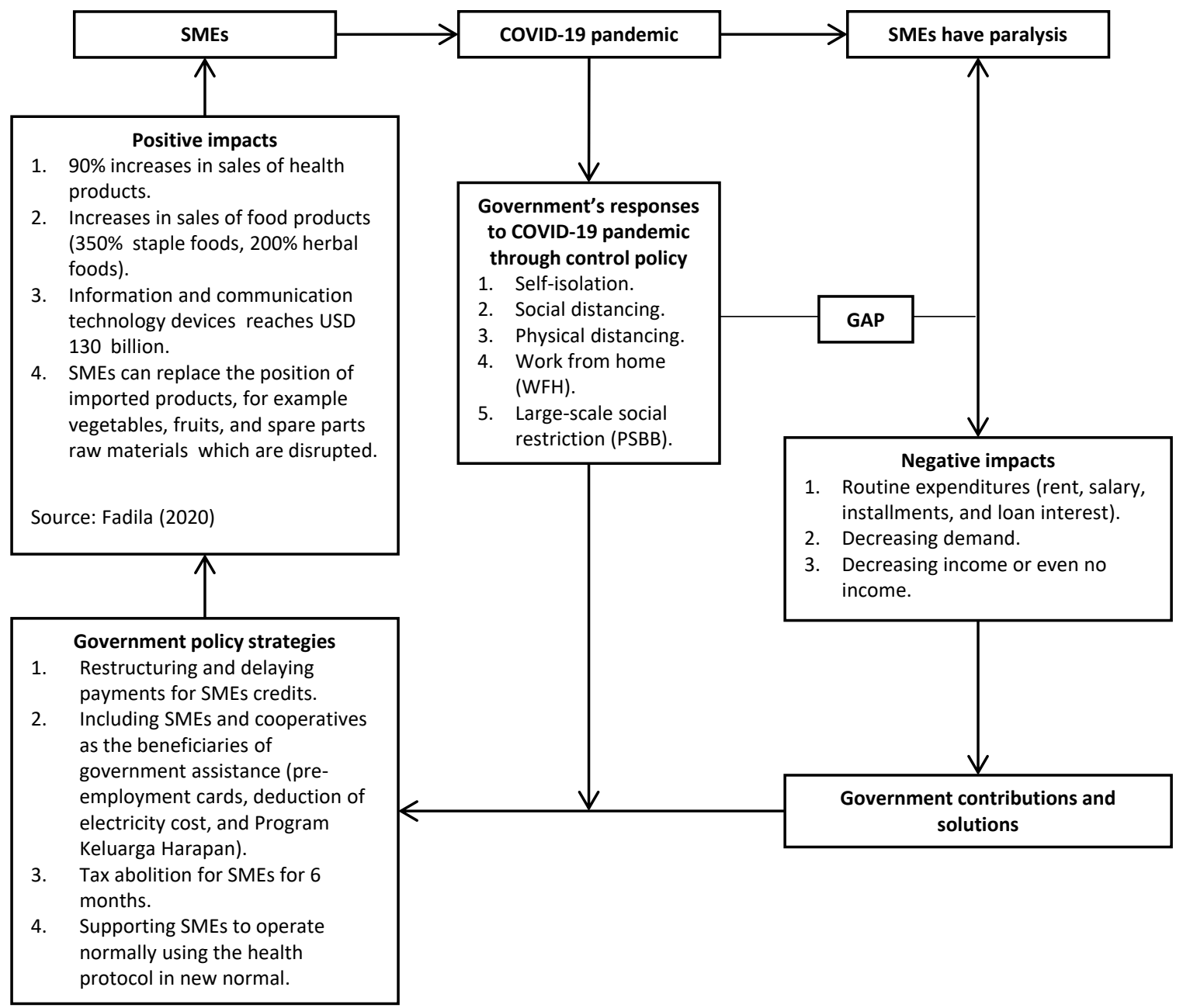

Figure 1. Theoretical framework

erate non-optimally and are required to strictly apply the COVID-19 protocol. It has significantly decreased the demand for SMEs' products. Thus, the government needs to issue policies to support SMEs in Indonesia to take roles in the domestic sector due to no export activity (see Figure 1).

\section{METHODS}

This study used a quantitative method with a survey design. This study conducted a survey on SMEs in Indonesia regarding the implementation of social distancing policies. The data were collected through observations, questionnaires, and literature studies. The samples were SMEs in Indonesia affected by social distancing policies during the COVID-19 pandemic, and these samples were randomly selected. It means that all
SMEs affected by COVID-19 have the opportunity to be involved as research samples. It involved a total of 587 respondents of SMEs in Indonesia. The characteristics of the respondents are formulated based on the result of the questionnaire. The characteristics cover gender, type of business, and business category owned by the respondent.

The data were analyzed using descriptive statistics with SPSS software. Descriptive statistics data describe the research sample summarized in numbers in a valid and meaningful way (Mishra et al., 2019; Thompson, 2009), and the information is presented in the simplest possible way (Mishra et al., 2019). This study focused on measures of central tendency using mean values. The mean value was generated from subtracting the highest value with the lowest value from the Likert scale and then divided by the number of interval classes. 


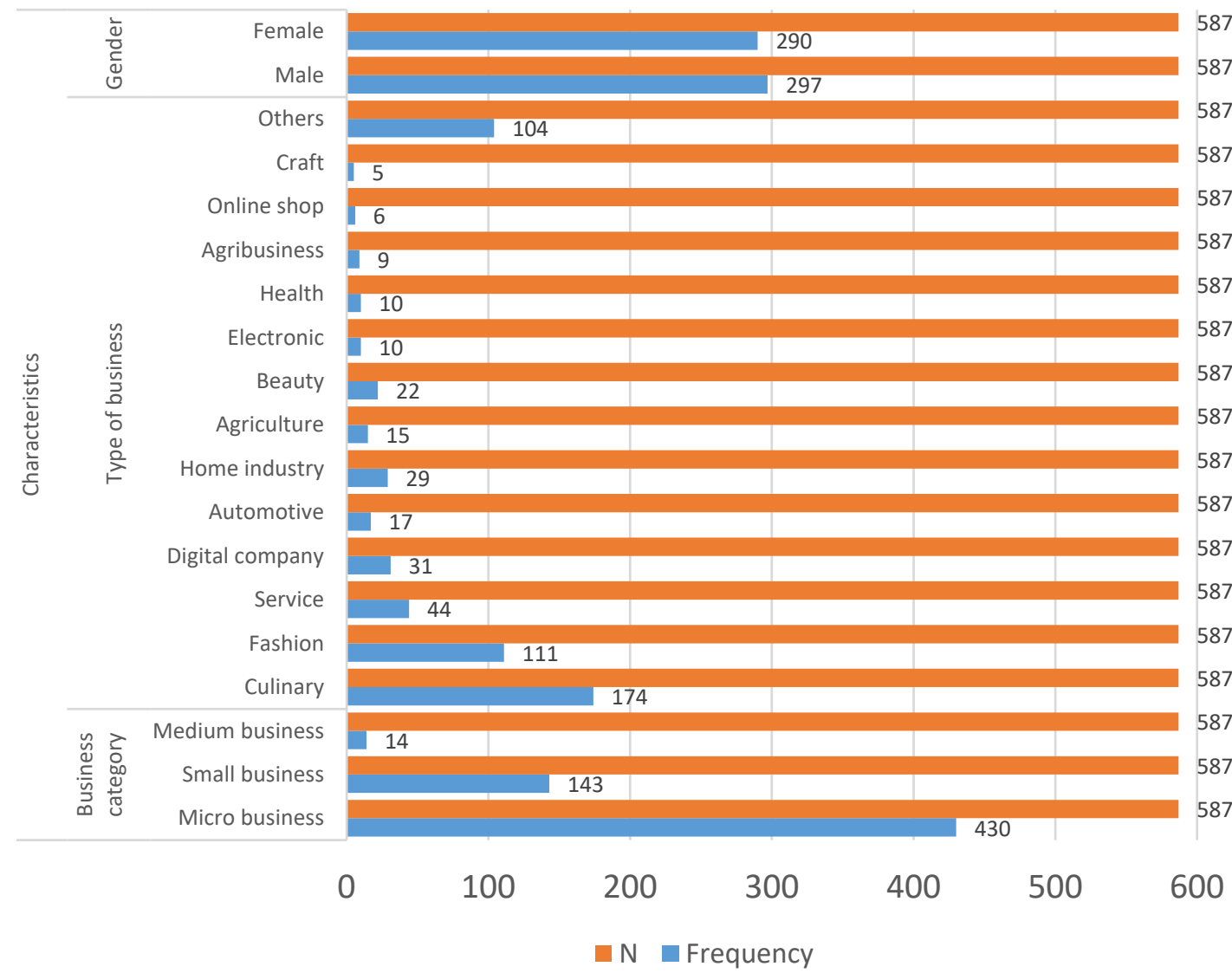

Figure 2. Characteristics of respondents

The mean value is categorized into very high (4.205.00), high (3.40-4.19), moderate (2.60-3.39), low (1.80-2.59), and very low (1.00-1.79). This interpretation results are the basis for determining the meaning of each question item in the discussion.

\section{RESULTS}

The result of this study presents the findings and elaboration of descriptive statistical results and government policies on SMEs' sustainability.

\subsection{Descriptive statistics results}

Descriptive statistics used in this study is a central tendency in the form of mean values. The result of statistical tests for each question given to the respondent can be seen in Table 1.

The descriptive statistics analysis results showed that the COVID-19 pandemic has greatly affected SMEs, especially due to the implementation of social dis- tancing policies. Indeed, the SMEs in Indonesia continued to operate by following government recommendations. There were concerns about business continuity, the use of information technology, business burdens due to policies and pandemics, making in business planning, and termination of employment. Those conditions illustrate the SMEs during the implementation of social distancing policies in Indonesia. Further, SMEs have also felt the negative impact of policies and the COVID-19 pandemic, such as decreased demand, problematic supply chains, and increased raw material costs. In general, social distancing policies have significantly affected business operations during the pandemic. Globally and nationally, the COVID-19 pandemic threatens SMEs' survival (Gustavsson \& Larsson, 2020), including in Indonesia, especially during the implementation of social distancing policies. Although social distancing policies influence sMEs' continuity, SMEs continue to operate by following the health protocols. SMEs can be successful during a pandemic by complying with health protocols (Saidu \& Aifuwa, 2020). 
Table 1. Descriptive statistics

\begin{tabular}{|c|c|c|c|}
\hline Questions & $\mathbf{N}$ & Mean & Std. Deviation \\
\hline Social distancing policies affect business operations. & 587 & 4.0051 & .90409 \\
\hline The COVID-19 pandemic highly affected businesses. & 587 & 4.7905 & .66511 \\
\hline $\begin{array}{l}\text { My business income declines/ social distancing does not cause employment termination in } \\
\text { my business. }\end{array}$ & 587 & 4.3731 & 1.17808 \\
\hline Social distancing does not reduce demand. & 587 & 2.4037 & 1.02470 \\
\hline Business plans change during the pandemic. & 587 & 4.7070 & .84821 \\
\hline Supply chains are in trouble during the pandemic. & 587 & 4.5826 & .89818 \\
\hline The Rupiah exchange rate affects business. & 587 & 2.9063 & 1.05953 \\
\hline The current pandemic raises concerns about the sustainability of the business. & 587 & 4.8416 & .56076 \\
\hline The government plays a role in supporting SMEs and large businesses during the pandemic. & 587 & 4.6031 & .88263 \\
\hline $\begin{array}{l}\text { Information technology plays a crucial role during the implementation of social distancing } \\
\text { policy. }\end{array}$ & 587 & 4.8109 & .66867 \\
\hline $\begin{array}{l}\text { SMEs follow government recommendations during the implementation of social distancing } \\
\text { policy (wearing masks, provide handwashing facilities, and maintain physical distance). }\end{array}$ & 587 & 4.9489 & .37514 \\
\hline The raw material costs and production costs increase during the pandemic. & 587 & 4.2555 & 1.18413 \\
\hline
\end{tabular}

\subsection{Government policies in economic recovery and sustainability of SMES}

The government continues to review policies and respond to the current situation to prevent the worst scenario in the economy and health sectors. Stimulus policy packages I-III was issued as steps to strengthen social and economic protection against the COVID-19 pandemic impact. The first stimulus policy focuses on strengthening the 2020 domestic economy through spending. The policy includes accelerated disbursement of capital expenditures, social assistance, transfers to regional and village funds, expansion of sembako cards (staple food), changing interest subsidies, incentives in the tourism sector, and pre-employment cards.

Then, the second stimulus policy focuses on maintaining the public's purchasing power and facilitating export-import. This package II policy was carried out through fiscal and non-fiscal policies. Relaxation of income tax $(\mathrm{PPh})$ article 21 for workers in the manufacturing sector and article 22 for 19 sectors, 30 percent deduction of income tax of article 25, and relaxation of VAT refunds for 19 sectors were carried out as fiscal policy measures. Meanwhile, non-fiscal policies are such as simplifying prohibition and restriction of export and imports and enhancing and accelerating export-import services. The monetary stimulus mix and the financial sector were also optimized to support the economy and maintain stability. This monetary stimulus was in the form of lowering the BI 7-Day Repo Rate, loosening the macro-prudential intermediation ratio, increasing the intensity of the triple intervention, expanding the underlying DNDF transactions, and supporting the distribution of noncash funds. The banking sector and finance companies' stimulus was through improving credit quality to make it smoother after the restructuration. Besides, credit quality assessment was only based on the timeliness of principal and/or interest payments up to Rp. 10 billion.

The third stimulus focuses on health management, social assistance, business assistance, and economic recovery. The combination of this stimulus was to prevent a deep and sustained economic crisis. Additional spending and financing in the health sector reached Rp. 75 trillion. The budget was to subsidize the tariff adjustment for non-paid workers and non-workers (Rp. 3 trillion), incentives for central and local medical personnel (Rp. 5.9 trillion), gifts for the death of health workers (Rp. 0.3 trillion), and spending on health management (Rp. 65.8 trillion).

Meanwhile, additional spending on social assistance reached Rp. 110 trillion. The budget covered the addition of a social safety network (Rp. 65 trillion), reserves for basic needs and market or logistics operations (Rp. 25 trillion), and adjustments to the education budget for handling COVID-19 (Rp. 20 trillion). In supporting the industry, the additional funding reached Rp. 70.1 trillion, while the financing to support the national economic recovery program was Rp. 150 trillion. 
Thus, for the sustainability of SMEs during the COVID-19 pandemic, the government of Indonesian has also issued policies that include:

1. Restructuring and delaying payments for SMEs credit.

2. Include SMEs and cooperatives as beneficiaries of government assistance (pre-employment card, deduction of electricity cost, and Program Keluarga Harapan).

3. Tax abolition policy for SMEs for 6 months.

4. Supporting SMEs to operate normally by applying the health protocol in new normal.

\section{DISCUSSION}

In normal days, many SMEs have difficulties in accessing working capital (Lee et al., 2015; Psillaki \& Eleftheriou, 2015). It is because of many factors, such as access to banks, government regulations, and others. The difficulties get greater during the COVID-19 pandemic, and it even worsens the economic condition. The economy was already poor before COVID-19 hit (Dev \& Sengupta, 2020). COVID-19 has triggered fears of an economic crisis and recession that will indirectly affect the global economy (Nicola et al., 2020). This condition affects all areas of the economy, including companies' sustainability, especially small and medium-sized enterprises (SMEs). COVID-19 has a significant negative impact on SMEs in both developed and developing countries (Lu et al., 2020), including Indonesia.

SMEs of many countries have the same obstacles (Lu et al., 2020). Before the crisis, the results of research showed that many companies experienced difficulties in accessing capital (Lee et al., 2015). The difficulties even get greater during the COVID-19 pandemic. In Indonesia, SMEs face the same problem as those in other countries. Many SMEs are required not to operate because of the government's control policy. Social restrictions, self-isolation, and travel restrictions affect the economy and cause job termination (Nicola et al., 2020). This condition makes it difficult for SMEs to pay regular expenses, such as rent, sal- aries, or loan interest. Besides, SMEs have to ensure the sustainability of their business during the pandemic.

The result showed that the majority of business actor respondents experienced the impact of social distancing policies. The COVID-19 pandemic heavily burdens the businesses. It decreases the income because of declining demand and problematic supply chains, which increases raw material costs and production costs during the pandemic. Globally the supply chain also experiences major problems and changes caused by the COVID-19 pandemic (Gray, 2020; Ivanov, 2020; OECD, 2020b). This study also illustrates that social distancing policies affect the income of SMEs in which it significantly decreases. This condition occurs not only in Indonesia but also in many other countries, including Ukraine and Turkey. The quarantine policy has weakened the financial condition of the tourism industry in Turkey (Kayalica, 2020).

The social distancing policy restricts economic activities (Kayalica, 2020) as it reduces income and damages supply chains. This study reveals that the social distancing policy does not cause termination of employment as the government has issued policies to maintain SMEs during a pandemic such as through restructuration and delaying payments for SME loans; include SMEs and cooperatives as beneficiaries of government assistance (pre-employment card, deduction of electricity cost, and Program Keluarga Harapan); tax abolition policy for SMEs for 6 months; and supporting SMEs to operate normally by applying the health protocol in new normal. The policy keeps SMEs operating because, during the pandemic, the government has a responsibility to support and maintain SMEs and large businesses in Indonesia.

The COVID-19 pandemic impacts the economy, particularly small businesses (Bartik et al., 2020a). The study results showed that the most affected business category is micro and small businesses, especially culinary, fashion, service, digital companies, home industries, and others. This condition raises concerns about the sustainability of businesses in Indonesia so that SMEs' business plans change during the pandemic. The SMEs that previously operated directly or face-to-face have 
made strategic changes by utilizing technology. Many experts state that increasing the productivity and performance of SMEs requires the role of digital technology (Papadopoulos et al., 2020).

Digital technology plays an important role in the social distancing policy as SMEs must implement social distancing policy (wearing masks, providing handwashing facilities, and maintaining physical distance). Therefore, many affected SMEs utilize online transportation services to deliver their products. This method helps SMEs survive during the pandemic because people are advised to maintain physical distancing and avoid gathering in the crowd. The condition of SMEs in Indonesia is quite similar to those in other countries during the implementation of social distancing policy; for example, food delivery services increase in Canada (Gray, 2020). This means that SMEs in Canada and Indonesia utilize delivery service to keep the business operating.

The situation during the COVID-19 pandemic is indeed difficult for business actors in Indonesia and other countries. Even the impact of the COVID-19 pandemic in the economic sector is greater than the previous pandemic, such as the 1918 influenza epidemic (Barrot et al., 2020; Garrett, 2008). At that time, the economic sector was not as poor as today. This condition makes many businesses, including SMEs, have difficulty in surviving, and some have been closed down. COVID-19 has temporarily closed many businesses (Bartik et al., 2020a, 2020b). Businesses have varying beliefs during COVID-19 (Bartik et al., 2020b). Thus, SMEs have to change strategies to survive the pandemic.

Specifically, the impact of COVID-19 in Indonesia is significantly different from the economic crisis several years ago. During the economic crisis in 1998, SMEs became the savior of the national economy in which many large businesses such as banking collapsed; meanwhile, SMEs exports increased by $350 \%$. In this current pandemic, domestic and global economic decline is due to the decreased demand for exports (Santia, 2020). Community needs and purchase power have significantly decreased, especially the need for commodities and manufactured products (Nicola et al., 2020). Most cooperatives affected by COVID-19 are engaged in daily necessities (services and production) experienced decreased sales, lack of capital, and distribution constraints. Meanwhile, the most affected SMEs are in the food and beverages sector and the creative and agricultural industries (Fadila, 2020). This situation results in business closure and termination of employment. Even though SMEs became the savior of the national economy in the 1998 crisis, it is different in this current pandemic. Indeed, there is no significant employment termination as the government responded with economic stimulus policy (I, II, III) to sustain SMEs during the COVID-19 pandemic. Specifically for SMEs, the government of Indonesian has issued a policy of restructuring and delaying payment for SMEs credit, including SMEs and cooperatives as beneficiary of government assistance (pre-employment cards, deduction of electricity cost, and Program Keluarga Harapan), tax abolition policies for SMEs for 6 months, and supporting SMEs to operate normally by applying the health protocol in new normal.

The emerging problem during the COVID-19 pandemic indicates that the COVID-19 pandemic greatly affects SMEs' sustainability activities in Indonesia and other countries. It reduces the demand for SMEs' products, affecting the financial conditions (Cashflow), which in the end causes SMEs unable to pay the credit, interest, and even taxes (Santia, 2020). However, the problems faced by SMEs in Indonesia during the COVID-19 pandemic are responded to by the government through the issue of economic stimulus policies to prevent the worst scenario in the economy and health sectors in Indonesia.

\section{CONCLUSION}

The COVID-19 pandemic affects all aspects of life, including the economy, which forces governments in many countries, including Indonesia, to implement social distancing policies. The result of this study indicates that the social distancing policy significantly affected business players, especially SMEs. SMEs' 
activities in Indonesia are disrupted because they cannot operate as usual, resulting in decreasing demand and income. Meanwhile, SMEs need to keep paying regular expenses such as salaries, rent, installments, and bank interest. The finding shows that SMEs in Indonesia do not terminate employment as the government has issued an economic stimulus policy to maintain SMEs by providing direct cash assistance, including SMEs employees as pre-employment cards, deduction of electricity cost, and Program Keluarga Harapan. This study contributes to SMEs in many countries to be more prepared in facing pandemic in the future.

The implementation of social distancing policies affects SMEs in Indonesia and those in other countries that implement the social distancing policy. The social distancing policy aims to stop the transmission of COVID-19, but it also impacts the activities of SMEs. This country disturbs the business activities, decreases demand and income, and increases raw material costs due to problematic supply chains. This condition raises concerns that force SMEs to change planning and implement new strategies by utilizing online-based information and delivery service. It is following government policies. This study contributes to SMEs in many countries to be more prepared in facing pandemic in the future.

The presence and roles of the government in maintaining the establishment of SMEs through policies is essential. In Indonesia, the government has played its role by issuing economic stimulus policies that positively affect the SMEs during this pandemic.

\section{AUTHOR CONTRIBUTIONS}

Conceptualization: Muhtar Lutfi, Pricylia Chintya Dewi Buntuang, Bakri Hasanuddin.

Data curation: Muhtar Lutfi, Pricylia Chintya Dewi Buntuang.

Formal analysis: Pricylia Chintya Dewi Buntuang, Bakri Hasanuddin.

Funding acquisition: Muhtar Lutfi.

Investigation: Pricylia Chintya Dewi Buntuang, Yoberth Kornelius, Erdiyansyah.

Methodology: Pricylia Chintya Dewi Buntuang, Erdiyansyah, Bakri Hasanuddin.

Project administration: Muhtar Lutfi, Erdiyansyah.

Resources: Muhtar Lutfi, Yoberth Kornelius.

Software: Yoberth Kornelius.

Supervision: Muhtar Lutfi, Bakri Hasanuddin.

Validation: Erdiyansyah.

Visualization: Erdiyansyah.

Writing - original draft: Muhtar Lutfi, Pricylia Chintya Dewi Buntuang, Erdiyansyah.

Writing - review \& editing: Pricylia Chintya Dewi Buntuang, Erdiyansyah.

\section{REFERENCES}

1. Ahmed, F., Zviedrite, N., \& Uzicanin, A. (2018). Effectiveness of workplace social distancing measures in reducing influenza transmission: A systematic review. BMC Public Health, 18(1), 518. https://doi.org/10.1186/s12889018-5446-1

2. Anderson, R. M., Heesterbeek, H., Klinkenberg, D., \& Hollingsworth, T. D. (2020). How will country-based mitigation measures influence the course of the COVID-19 epidemic? The Lancet, 395(10228), 931-934. https://doi.org/10.1016/S01406736(20)30567-5

3. Barrot, J.-N., Grassi, B., \& Sauvagnat, J. (2020). Sectoral Effects of Social Distancing (SSRN Scholarly Paper ID 3569446). Social Science Research Network. https://doi.org/10.2139/ ssrn.3569446

4. Bartik, A. W., Bertrand, M., Cullen, Z. B., Glaeser, E. L., Luca,
M., \& Stanton, C. T. (2020a). How Are Small Businesses Adjusting to COVID-19? Early Evidence from a Survey (Working Paper No. 26989; Working Paper Series). National Bureau of Economic Research. https://doi.org/10.3386/w26989

5. Bartik, A. W., Bertrand, M., Cullen, Z., Glaeser, E. L., Luca, M., \& Stanton, C. (2020b). The impact of COVID-19 on small business outcomes and expectations. Proceedings of the 
National Academy of Sciences, 117(30), 17656-17666. https://doi. org/10.1073/pnas.2006991117

6. Baum, N. M., Jacobson, P. D., \& Goold, S. D. (2009). "Listen to the People": Public Deliberation About Social Distancing Measures in a Pandemic. The American Journal of Bioethics, 9(11), 4-14. https://doi. org/10.1080/15265160903197531

7. Brussevich, M., Dabla-Norris, E., \& Khalid, S. (2020a, June 15). Effects of lockdowns around world likely to have lasting impact. Irish Sun. Retrieved from https://www. irishsun.com/news/265446508/effects-of-lockdowns-around-worldlikely-to-have-lasting-impact

8. Brussevich, M., Dabla-Norris, E., \& Khalid, S. (2020b). Who will Bear the Brunt of Lockdown Policies? Evidence from Teleworkability Measures Across Countries (IMF Working Papers, 20/88). Retrieved from https:// www.imf.org/en/Publications/WP/ Issues/2020/06/12/Who-will-Bearthe-Brunt-of-Lockdown-PoliciesEvidence-from-Tele-workabilityMeasures-Across-49479

9. Brynjolfsson, E., Horton, J. J., Ozimek, A., Rock, D., Sharma, G., \& TuYe, H.-Y. (2020). COVID-19 and Remote Work: An Early Look at US Data (Working Paper No. 27344; Working Paper Series). National Bureau of Economic Research. https://doi.org/10.3386/ w27344

10. Cauchemez, S., Ferguson, N. M., Wachtel, C., Tegnell, A., Saour, G., Duncan, B., \& Nicoll, A. (2009). Closure of schools during an influenza pandemic. The Lancet Infectious Diseases, 9(8), 473-481. https://doi.org/10.1016/S14733099(09)70176-8

11. Clerkin, K. J., Fried, J. A., Raikhelkar, J., Sayer, G., Griffin, J. M., Masoumi, A., Jain, S. S., Burkhoff, D., Kumaraiah, D., Rabbani, L., Schwartz, A., \& Uriel, N. (2020). COVID-19 and Cardiovascular Disease. Circulation, 141(20), 1648-1655. https://doi.org/10.1161/CIRCULATIONAHA.120.046941

12. Dev, S. M., \& Sengupta, R. (2020). Covid-19: Impact on the Indian economy. Indira Gandhi Institute of Development Research, Mumbai.

13. Doshi, H., Kumar, P., \& Yerramilli, V. (2017). Uncertainty, Capital Investment, and Risk Management. Management Science, 64(12), 5769-5786. https:// doi.org/10.1287/mnsc.2017.2815

14. Fadila, R. U. (2020, May 9). 1.785 Koperasi dan 163.713 UMKM Terdampak Pandemi Covid-19 Pikiran-Rakyat.com. Retrieved from https://www.pikiran-rakyat. com/ekonomi/pr-01379615/1785koperasi-dan-163713-umkmterdampak-pandemi-covid-19

15. Farboodi, M., Jarosch, G., \& Shimer, R. (2020). Internal and external effects of social distancing in a pandemic. National Bureau of Economic Research.

16. Ferguson, N. M., Cummings, D. A. T., Cauchemez, S., Fraser, C., Riley, S., Meeyai, A., Iamsirithaworn, S., \& Burke, D. S. (2005). Strategies for containing an emerging influenza pandemic in Southeast Asia. Nature, 437(7056), 209214. https://doi.org/10.1038/nature04017

17. Ferguson, N. M., Cummings, D. A. T., Fraser, C., Cajka, J. C., Cooley, P. C., \& Burke, D. S. (2006). Strategies for mitigating an influenza pandemic. Nature, 442(7101), 448-452. https://doi. org/10.1038/nature04795

18. Garrett, T. A. (2008). Pandemic economics: The 1918 influenza and its modern-day implications. Federal Reserve Bank of St. Louis Review, 90, 75-94.

19. Glass, R. J., Glass, L. M., Beyeler, W. E., \& Min, H. J. (2006). Targeted Social Distancing Designs for Pandemic Influenza. Emerging Infectious Diseases, 12(11), 1671-1681. Retrieved from https://www.ncbi.nlm.nih.gov/ pmc/articles/PMC3372334/

20. Gray, R. S. (2020). Agriculture, transportation, and the COVID-19 crisis. Canadian Journal of Agricultural Economics/ Revue Canadienne d'agroeconomie, 68(2), 239-243. https://doi. org/10.1111/cjag.12235
21. Gustavsson, S., \& Larsson, S. (2020). Marketing Innovation for SMEs during COVID-19 Pandemic: A case study of the hospitality industry in Norrbotten. Retrieved from http://urn.kb.se/resolve?urn =urn:nbn:se:ltu:diva-79426

22. Herbane, B. (2010). Small business research: Time for a crisis-based view. International Small Business Journal, 28(1), 43-64. https://doi. org/10.1177/0266242609350804

23. Huang, C., Wang, Y., Li, X., Ren, L., Zhao, J., Hu, Y., Zhang, L., Fan, G., Xu, J., Gu, X., Cheng, Z., Yu, T., Xia, J., Wei, Y., Wu, W., Xie, X., Yin, W., Li, H., Liu, M., ... Cao, B. (2020). Clinical features of patients infected with 2019 novel coronavirus in Wuhan, China. The Lancet, 395(10223), 497-506. https://doi.org/10.1016/S01406736(20)30183-5

24. Imai, N., Gaythorpe, K. A. M., Abbott, S., Bhatia, S., van Elsland, S., Prem, K., Liu, Y., \& Ferguson, N. M. (2020). Adoption and impact of non-pharmaceutical interventions for COVID-19. Wellcome Open Research, 5, 59. https://doi.org/10.12688/wellcomeopenres.15808.1

25. Ivanov, D. (2020). Predicting the impacts of epidemic outbreaks on global supply chains: A simulation-based analysis on the coronavirus outbreak (COVID-19/ SARS-CoV-2) case. Transportation Research Part E: Logistics and Transportation Review, 136, 101922. https://doi.org/10.1016/j. tre.2020.101922

26. Javed, S. A., \& Ayaz, M. U. (2020). PROJECTED IMPACT OF LOCKDOWN ON SMES IN PAKISTAN. Sustainable Development Policy Institute; JSTOR. https://doi.org/10.2307/ resrep24349

27. Jones, C. J., Philippon, T., \& Venkateswaran, V. (2020). Optimal mitigation policies in a pandemic: Social distancing and working from home. National Bureau of Economic Research.

28. Kayalica, M. O. (2020, May 12). World against COVID-19. Our colleagues' thoughts about the situation: M. Ozgur Kayalica. 
Retrieved from https://businessperspectives.org/news/ world-against-covid-19-ourcolleagues-thoughts-about-thesituation-m-ozgur-kayalica

29. Lee, N., Sameen, H., \& Cowling, M. (2015). Access to finance for innovative SMEs since the financial crisis. Research Policy, 44(2), 370-380. https://doi. org/10.1016/j.respol.2014.09.008

30. Lewnard, J. A., \& Lo, N. C. (2020) Scientific and ethical basis for social-distancing interventions against COVID-19. The Lancet Infectious Diseases, 20(6), 631-633. https://doi.org/10.1016/S14733099(20)30190-0

31. Lu, Y., Wu, J., Peng, J., \& Lu, L. (2020). The perceived impact of the Covid-19 epidemic: Evidence from a sample of 4807 SMEs in Sichuan Province, China. Environmental Hazards, 19(4), 323-340. https://doi.org/10.1080/1 7477891.2020 .1763902

32. Mishra, P., Pandey, C. M., Singh, U., Gupta, A., Sahu, C., \& Keshri, A. (2019). Descriptive Statistics and Normality Tests for Statistical Data. Annals of Cardiac Anaesthesia, 22(1), 67-72. https:// doi.org/10.4103/aca.ACA_157_18

33. Nicola, M., Alsafi, Z., Sohrabi, C., Kerwan, A., Al-Jabir, A., Iosifidis, C., Agha, M., \& Agha, R. (2020). The socio-economic implications of the coronavirus pandemic (COVID-19): A review. International Journal of Surgery, 78, 185-193. https://doi.org/10.1016/j. ijsu.2020.04.018

34. Nyanga, T., \& Zirima, $\mathrm{H}$. (2020). Reactions of small to medium enterprises in masvingo, zimbabwe to covid 19: Implications on productivity. Business Excellence and Management, 10(1), 22-32.

35. OECD. (2020a, June). OECD Economic Outlook, June 2020. The world economy on a tightrope. Retrieved from http://www.oecd.org/ economic-outlook/june-2020

36. OECD. (2020b, July 15). Coronavirus (COVID-19): SME policy responses. Retrieved from http://www.oecd.org/coronavirus/ policy-responses/coronaviruscovid-19-sme-policy-responses04440101/\#section-d1e16329

37. Omar, A. R. C., Ishak, S., \& Jusoh, M. A. (2020). The impact of Covid-19 Movement Control Order on SMEs' businesses and survival strategies. GeografiaMalaysian Journal of Society and Space, 16(2), 2. Retrieved from http://ejournals.ukm.my/gmjss/ article/view/40125

38. Papadopoulos, T., Baltas, $\mathrm{K}$. N., \& Balta, M. E. (2020). The use of digital technologies by small and medium enterprises during COVID-19: Implications for theory and practice. International Journal of Information Management, 102192. https://doi.org/10.1016/j.ijinfomgt.2020.102192

39. Psillaki, M., \& Eleftheriou, K. (2015). Trade Credit, Bank Credit, and Flight to Quality: Evidence from French SMEs. Journal of Small Business Management, 53(4), 1219-1240. https://doi. org/10.1111/jsbm.12106

40. Reluga, T. C. (2010). Game Theory of Social Distancing in Response to an Epidemic. PLOS Computational Biology, 6(5), e1000793. https://doi.org/10.1371/ journal.pcbi.1000793

41. Saidu, M., \& Aifuwa, H. O. (2020). Coronavirus Pandemic in Nigeria: How Can Small and Medium Enterprises (SMEs) Cope and Flatten the Curve. European Journal of Accounting, Finance and Investment, 6(5), 55-61.

42. Santia, T. (2020, April 15). Beda Kondisi UMKM Saat Pandemi Corona di 2020 dengan Krisis Ekonomi 1998. Retrieved from https://www.liputan6.com/bisnis/ $\mathrm{read} / 4228397 /$ beda-kondisiumkm-saat-pandemi-corona-di2020-dengan-krisis-ekonomi-1998

43. Syafri, H., Sangadji, E., \& Utami, R. R. M. (2020). Impact Analysis of the Large-Scale Social Restrictions (PSBB) Policy Implementation in Jakarta. Journal of Indonesian Health Policy and Administration, 5(2), 57-60. https://doi.org/10.7454/ihpa. v5i2.4056
44. Thompson, C. B. (2009).

Descriptive data analysis. Air Medical Journal, 28(2), 56-59.

45. Thorgren, S., \& Williams, T. A. (2020). Staying alive during an unfolding crisis: How SMEs ward off impending disaster. Journal of Business Venturing Insights, 14, e00187. https://doi.org/10.1016/j. jbvi.2020.e00187

46. Wang, Y., Hong, A., Li, X., \& Gao, J. (2020). Marketing innovations during a global crisis: A study of China firms' response to COVID-19. Journal of Business Research, 116, 214-220. https://doi org/10.1016/j.jbusres.2020.05.029

47. Weill, J. A., Stigler, M., Deschenes, O., \& Springborn, M. R. (2020). Social distancing responses to COVID-19 emergency declarations strongly differentiated by income. Proceedings of the National Academy of Sciences, 117(33), 19658-19660. https://doi. org/10.1073/pnas.2009412117

48. Wilder-Smith, A., \& Freedman, D. O. (2020). Isolation, quarantine, social distancing and community containment: Pivotal role for old-style public health measures in the novel coronavirus (2019$\mathrm{nCoV}$ ) outbreak. Journal of Travel Medicine, 27(2). https://doi. org/10.1093/jtm/taaa020

49. Winarsih, Indriastuti, M., \& Fuad, K. (2020). Impact of Covid-19 on Digital Transformation and Sustainability in Small and Medium Enterprises (SMEs): A Conceptual Framework. In L. Barolli, A. Poniszewska-Maranda, \& T. Enokido (Eds.), Complex, Intelligent and Software Intensive Systems (pp. 471-476). Springer International Publishing. https:// doi.org/10.1007/978-3-030-504540_48

50. World Health Organization. (2020). Modes of transmission of virus causing COVID-19: Implications for IPC precaution recommendations: scientific brief. Retrieved from https://apps.who.int/iris/bitstream/ handle/10665/331601/WHO2019-nCoV-Sci_Brief-Transmission_modes-2020.1-eng.pdf 
51. Yi, V. Z. (2020). Struggle of Malaysian SMEs During the COVID-19 Pandemic. KSI

Strategic Institute for Asia Pacific. Retrieved from https://kasi.asia/ wp-content/uploads/2020/05/KSIPolicy-Brief-Struggle-of-Malaysian-SMEs-During-the-COVID19-Pandemic.pdf
52. Zachariadis, M., Ozcan, P., \& Dinçkol, D. (2020). The Covid-19 impact on fintech: Now is the time to boost investment. LSE Business Review. Retrieved from http:// eprints.lse.ac.uk/104463/3/businessreview_2020_04_13_the_covid_19_impact_on_fintech_now_ is_the.pdf
53. Zu, Z. Y., Jiang, M. D., Xu, P. P., Chen, W., Ni, Q. Q., Lu, G. M., \& Zhang, L. J. (2020). Coronavirus Disease 2019 (COVID-19): A Perspective from China. Radiology, 296(2), E15-E25. https://doi.org/10.1148/radiol.2020200490 